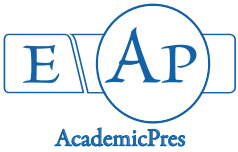

Odala AA et al. (2020)

Notulae Scientia Biologicae 12(3):608-618

DOI: $10.15835 / \mathrm{nsb} 12310770$

Research Article

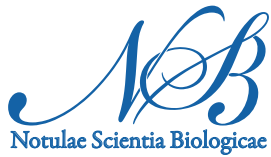

\title{
Plant parasitic nematode communities associated with the crop banana (Musa spp.) at Attappady Tribal hill area, India
}

\author{
Ashfak A. ODALA ${ }^{1 *}$, Rasmi A. RAMANATHAN ${ }^{1}$, Usman ARERATH ${ }^{2}$ \\ ${ }^{I}$ Government Victoria College (Affiliated to University of Calicut), PG \& Research Department of Botany, Palakkad, Kerala, \\ India; ashfubot@gmail.com ("corresponding author); rasmi_ar@yahoo.com \\ ${ }^{2}$ KAHM Unity Women's College (Affiliated to University of Calicut), Department of Botany, Manjeri, Kerala, \\ India; usmaanarerath@gmail.com
}

\begin{abstract}
Attappady is a region of immense biological importance comes under the Nilgiri Biosphere Reserve area of India at Palakkad district. Biodiversity study of this hill area has great importance in conservative science. Except a national range study for nematode fauna of banana (Musa spp.) in Indian banana fields, a detailed survey of this agriculturally and environmentally important area has not reported till now. The diversity analysis of plant parasitic nematodes was done with samples taken from rhizosphere soil and roots of banana at this area. Comparing with the reported nationwide study the present study newly reported the presence of Aphelenchus spp., Dorylaimoides spp., Hoplolaimus spp., Rotylenchulus spp., Tylenchorynchus spp. and Tylenchus spp. from the crop banana other than the already reported one's such as Helicotylenchus spp., Meloidogyne spp., Pratylenchusspp. and Radopholus spp. The analysis of nematode genera in different banana cultivars such as Musa $\times$ paradisiaca L. (AAB) 'Nendran', Musa acuminata Colla (AAA) 'Robusta', Musa acuminata Colla (AA) 'Kadali' and Musa $\times$ paradisiaca L. (Mysore AAB) 'Poovan' revealed differences in the reaction to attack between genotypes, and that the cultivar 'Nendran' was the most susceptible one to plant parasitic nematodes.
\end{abstract}

Keywords: Attappady; banana cultivars; comparison; diversity; nematode

Abbreviations: AAA: triploid cultivar derived from wild cultivar Musa acuminata (AA); AA: diploid cultivar derived from wild cultivar Musa acuminata (AA); AAB: cultivar derived from wild cultivars $M$. acuminata (AA) and M. balbisiana (BB)

\section{Introduction}

India is an agriculture country which bears first rank in the world for the production and area of cultivation of several crops including banana (Sheth, 2017). In Indian states, Kerala contributes a major portion to achieve this status of banana. The major share of Kerala's banana was got from the middle district Palakkad and in this Attappady hill area has the lion's contribution (Department of Economics and Statistics, 2017). Most of the regions of Attappady has been covered by forest and comes under the Nilgiri Biosphere Reserve area of India. The specific environmental features of this area altogether contribute climate and became a controlling factor for life cycle of pathogens. 
Among the pathogens of banana, plant parasitic nematodes have a crucial role in crop loss by decreased production (Quénéhervé, 1989). Under estimation it affects the banana crop at an average national loss of 21,068.73 million rupees in India (Jain et al., 2007). It results in reduced bunch size, delayed maturation time and reduced tolerance to other stresses (Kibria and Hoque, 2005). It also causes prone to tissue attack by bacteria, fungi and virus (Pinochet and Stover, 1980; Rotimi, 2003). So, evaluation of nematode diversity became very much value addition to the agriculture sector of the state. In the aspect of controlling them it should be started from knowing the diversity and distribution in the banana fields. Except a national range study for nematode fauna in Indian banana fields, a detailed survey at this agriculturally and environmentally important area has not reported yet. So, this study has great importance in conservative science. Thus, the present study focused a systematic survey on plant parasitic nematodes of the crop banana 'Nendran' at the Attappady hill area, Kerala, India. Along with this study, analysis was also carried out for comparing the nematode diversity and nematode population density in different banana cultivars such as 'Nendran' (AAB), 'Robusta' (AAA), 'Kadali' (AA), and 'Poovan' (Mysore AAB) available in this study area.

\section{Materials and Methods}

The study area lies in Mannarkkad taluk of Kerala at geographical co-ordinates between $10^{\circ} 55^{\prime} 10^{\prime \prime}$ and $11^{\circ} 15^{\prime} 19^{\prime \prime} \mathrm{N}$ latitudes and $76^{\circ} 27^{\prime} 11^{\prime \prime}$ and $76^{\circ} 48^{\prime} 8^{\prime \prime} \mathrm{E}$ longitudes. The altitude varies between 200 and 2400 meters above msl. Map of study area is given in Figure 1.

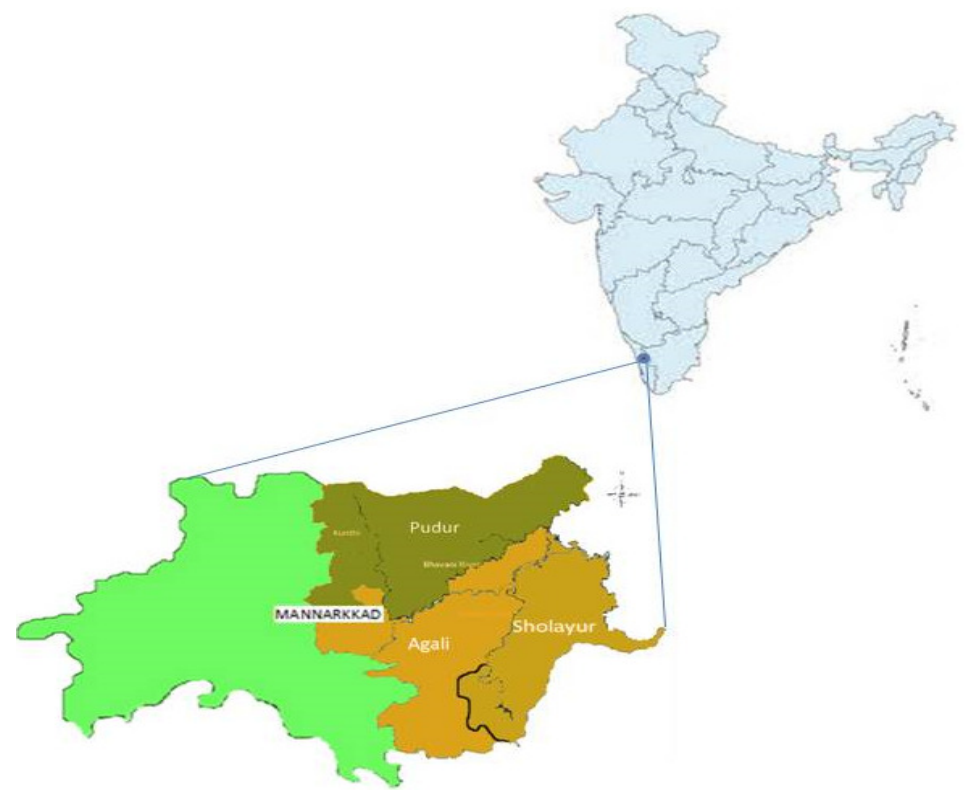

Figure 1. Map of Mannarkkad taluk in relation to India with indicating the three local self-government areas of Attappady hill area in which samples were taken

Source: https://mea.gov.in/india-at-glance.html

\section{Survey and sample collection}

Rhizosphere soil samples and root samples of banana were collected by an intensive survey through banana fields of Attappady hill area during the post monsoon season (August to December) of 2017. Thus, nine samples each were collected for both rhizosphere soil and roots for cultivar 'Nendran'. The soil was taken from $30-40 \mathrm{~cm}$ away and $25-30 \mathrm{~cm}$ deep beneath to the bole of the corm. One rhizosphere soil sample was made by mixing randomly collected three samples from a panchayath. The soil samples were collected and well 
packed, labeled in polythene bags. The observed data were arranged based on all three local governing bodies in the study area namely 'panchayaths' such as Agali panchayath, Pudur panchayath and Sholayur panchayath. For comparing the nematode population density between these panchayaths, rhizosphere soil and root samples were collected from the prominently cultivating banana cultivar 'Nendran'.

For comparing susceptibility towards nematodes between different cultivars present in the study area, the selected cultivars were Musa x paradisiaca L. (AAB) 'Nendran', Musa acuminata Colla (AAA) 'Robusta', Musa acuminata Colla (AA) 'Kadali' and Musa $x$ paradisiaca L. (Mysore AAB) 'poovan'. Nine samples collected from different banana fields were analysed for the prominently cultivating cultivar 'Nendran'. Based on availability of banana fields in Attappady hill area having at least 100 plants, three samples each were collected for other cultivars for both rhizosphere soil and roots. The cultivar 'Kadali' was collected from field located in Sholayur panchayath, the cultivar 'Robusta' was collected from field located in Pudur panchayath and cultivar 'Poovan (Mysore)' was collected from field located in Agali panchayath.

\section{Extraction of nematodes from soil samples}

After reaching the laboratory of KAHM Unity Women's College, Manjeri, samples were used for nematodes extraction. $250 \mathrm{~g}$ of rhizosphere soil was taken for Cobb's decanting and sieving method followed by Baermann funnel technique (Southey, 1986).

\section{Extraction of nematodes from root samples}

For these the infected root bits were taken from semi hard portion of the main roots. Then they were washed under tap water to remove adhered soil particles. From this $10 \mathrm{~g}$ of infected root (fresh weight) were cut into $4 \mathrm{~cm}$ sized pieces and macerated gently using kitchen mixer grinder (Panasonic, Japan). Then, these crushed roots were place over the tissue paper supported with gauge wire net placed in a plastic petri dish. Add some water and left for 16 hours for getting nematode suspension.

\section{Identification and analysis of samples for nematodes}

The clear nematode suspensions collected in plastic Petri dish were taken for observing nematodes. $5 \mathrm{ml}$ nematode suspension was taken into three transparent petri dishes after gentle shaking. Then each transparent petri dish with nematode suspension was placed under the camera attached stereo microscope (Magnus MSZTR) for observing the nematodes. Photographs were taken for the analysis by using camera attached compound microscope (Olympus CX2L $i$ ). Nematodes were identified by using diagrammatic key proposed by Ravichandra (2015). Number and genus of nematodes were recorded and analysed. The measures such as absolute density, absolute frequency and prominence value were taken for comparing the presence of nematode population between different cultivars and three panchayaths. Diversity was assessed based on the number of genera observed at a place. Another measure of severity of attack is done by checking Economic Threshold Level (ETL) ie, one larvae/g soil found, the area was considered as above ETL (Rajendran et al., 1980). The data on prominence value describes the density of a nematode as a factor of absolute frequency and absolute density of nematodes occurred in a region. Absolute Density (AD), Absolute Frequency (AF) and Prominence value (PV) were calculated by using the formula proposed by (Norton, 1978) as follows:

Absolute frequency $=$ Number of samples containing nematodes $/$ Number of samples collected $\times 100$

Absolute density $=$ Number of nematodes in all samples / Number of samples collected $\times 100$

Prominence value $=$ Absolute density $\times \sqrt{ }$ Absolute frequency 


\section{Results}

The observations showed that 'Nendran' (AAB) was the most prominently cultivating cultivar in Attappady hill area during 2016-2017. Other cultivars were found in small patches.

\section{Comparison between panchayaths for nematode abundance}

Observation of nematodes in banana ('Nendran') found nine different genera of plant parasitic nematodes from rhizosphere soil. The observed genera were Aphelenchus spp., Dorylaimoides spp., Helicotylenchusspp., Hoplolaimusspp., Meloidogynespp., Pratylenchusspp., Radopholus spp., Rotylenchulus spp. and Tylenchorynchus spp. Six different genera such as Aphelenchus spp., Helicotylenchus spp., Hoplolaimus spp., Meloidogyne spp., Pratylenchus spp. and Rotylenchulus spp. were the nematode genera found in root samples collected from this study area. In collected rhizosphere soil samples, the most frequently occurring plant parasitic nematode genera were Meloidogyne spp. and Rotylenchulus spp. with 100\% absolute frequency. These genera found in all studied panchayaths in both rhizosphere soil samples and root samples. Even though Rotylenchulus spp. were found in all panchayaths their frequency of occurrence was not in a level of wide spread at Sholayur panchayath.

Nematode diversity was analysed by observing the number of genera seen at a place. Thus, comparison between all three panchayaths of Attappady hill area revealed that all panchayaths showed five numbers of nematode genera in the soil samples. They are Aphelenchus spp., Dorylaimoides spp., Meloidogyne spp., Rotylenchulus spp. and Tylenchorynchus spp. in Agali panchayath, Helicotylenchus spp., Meloidogyne spp., Pratylenchus spp., Radopholus spp. and. Rotylenchulus spp. at Pudur panchayath and Helicotylenchus spp., Hoplolaimusspp. Meloidogyne spp., Pratylenchus spp. and Rotylenchulus spp. at Sholayur panchayath. But in root samples maximum diversity in nematode genera ie, five nematode genera per panchayath was found at Sholayur panchayath only. Among the observed nematode genera Radopholus spp. was the least found genus in the rhizosphere soil samples and Hoplolaimus spp. was the least found genus in root samples (Table 1). On analysing the soil samples for population density, 43.8\% nematodes were found in Agali panchayath followed by Sholayur panchayath (37.79\%) and Pudur panchayath (18.41\%) (Table 2). Root sample analysis showed the result as maximum population density of more than $50 \%$ of nematodes were found at Agali panchayath (50.78\%) followed by Sholayur panchayath (29.22\%) and Pudur panchayath (20\%) (Table 3).

Table 1. Nematode distribution in rhizosphere soil and root of banana 'Nendran' (AAB) samples at Attappady hill area

\begin{tabular}{|c|c|c|c|c|c|c|c|c|c|c|}
\hline Panchayaths & Sample & Aph & Dor & Hel & Hop & Mel & Pra & Rad & Rot & Tyr \\
\hline \multirow{2}{*}{ Agali } & SOIL & +++ & ++ & - & - & +++ & - & - & +++ & +++ \\
\cline { 2 - 13 } & ROOT & +++ & - & - & - & +++ & - & - & +++ & - \\
\hline \multirow{2}{*}{ Pudur } & SOIL & - & - & ++ & - & +++ & + & + & +++ & - \\
\cline { 2 - 12 } & ROOT & - & - & ++ & - & +++ & - & - & +++ & - \\
\hline \multirow{2}{*}{ Sholayur } & SOIL & - & - & +++ & +++ & +++ & +++ & - & +++ & - \\
\cline { 2 - 11 } & ROOT & - & - & +++ & + & +++ & + & - & ++ & - \\
\hline
\end{tabular}

$-=$ not recorded; $+=$ present in survey (present only in one observation); $++=$ common (present only in two observation; $+++=$ widespread (occurred in all three observations)

Aph - Aphelenchus spp.; Dor - Dorylaimoides spp.; Hel - Helicotylenchus spp.; Hop -Hoplolaimus spp.; Mel Meloidogyne spp.; Pra-Pratylenchusspp.; Rad-Radopholus spp.; Rot-Rotylenchulus spp.; Tyr - Tylenchorynchus spp. 
Table 2. Nematode population density in rhizosphere soil samples of banana 'Nendran' (AAB) in different panchayaths of Attappady hill area

\begin{tabular}{|c|c|c|c|c|c|c|c|c|c|c|c|}
\hline \multirow[b]{2}{*}{ Panchayaths } & \multirow{2}{*}{$\begin{array}{c}\text { Total } \\
\text { nematodes } \\
\text { in a } \\
\text { Panchayath }\end{array}$} & \multirow{2}{*}{$\begin{array}{c}\text { Percentage of } \\
\text { nematodes in a } \\
\text { panchayath }\end{array}$} & \multicolumn{9}{|c|}{ Total number of each nematode genera from all observations } \\
\hline & & & Aph & Dor & $\mathrm{Hel}$ & Hop & $\mathrm{Mel}$ & Pra & $\operatorname{Rad}$ & Rot & $T_{y r}$ \\
\hline Agali & 364 & 43.8 & $\begin{array}{l}113 \\
(44)\end{array}$ & $\begin{array}{c}3 \\
(2)\end{array}$ & 0 & 0 & $\begin{array}{l}199 \\
(73)\end{array}$ & 0 & 0 & $\begin{array}{l}16 \\
(8)\end{array}$ & $\begin{array}{c}33 \\
(13)\end{array}$ \\
\hline Pudur & 153 & 18.41 & 0 & 0 & $\begin{array}{c}28 \\
(16)\end{array}$ & 0 & $\begin{array}{c}74 \\
(31)\end{array}$ & $\begin{array}{c}10 \\
(10)\end{array}$ & $\begin{array}{c}2 \\
(2)\end{array}$ & $\begin{array}{c}39 \\
(16)\end{array}$ & 0 \\
\hline Sholayur & 314 & 37.79 & 0 & 0 & $\begin{array}{c}42 \\
(21)\end{array}$ & $\begin{array}{c}23 \\
(10)\end{array}$ & $\begin{array}{l}131 \\
(54)\end{array}$ & $\begin{array}{c}18 \\
(11)\end{array}$ & 0 & $\begin{array}{c}100 \\
(46)\end{array}$ & 0 \\
\hline \multicolumn{3}{|c|}{ Total of each genus } & 113 & 3 & 70 & 23 & 404 & 28 & 2 & 155 & 33 \\
\hline
\end{tabular}

${ }^{*}$ Parenthesis (maximum value attained);

Aph - Aphelenchus spp.; Dor - Dorylaimoides spp.; Hel - Helicotylenchus spp.; Hop - Hoplolaimus spp.; Mel Meloidogyne spp.; Pra - Pratylenchusspp.; Rad-Radopholus spp.; Rot-Rotylenchulus spp.; Tyr - Tylenchorynchus spp.

Table 3. Nematode population density in root samples of banana 'Nendran' (AAB) in different panchayaths of Attappady hill area

\begin{tabular}{|c|c|c|c|c|c|c|c|c|}
\hline \multirow{2}{*}{ Panchayaths } & \multirow{2}{*}{$\begin{array}{c}\text { Total nematodes } \\
\text { in a Panchayath }\end{array}$} & \multirow{2}{*}{$\begin{array}{c}\text { Percentage of } \\
\text { nematodes in } \\
\text { panchayath }\end{array}$} & \multicolumn{5}{|c|}{ Total number of each nematode genera from all } \\
& & & Aph & Hel & Hop & Mel & Pra & Rot \\
\cline { 4 - 10 } Agali & 358 & 50.78 & $\begin{array}{c}35 \\
(16)\end{array}$ & 0 & 0 & $\begin{array}{c}212 \\
(91)\end{array}$ & 0 & $\begin{array}{c}111 \\
(45)\end{array}$ \\
\hline Pudur & 141 & 20 & 0 & $\begin{array}{c}28 \\
(16)\end{array}$ & 0 & $\begin{array}{c}74 \\
(31)\end{array}$ & 0 & $\begin{array}{c}39 \\
(16)\end{array}$ \\
\hline Sholayur & 206 & 29.22 & 0 & $\begin{array}{c}31 \\
(13)\end{array}$ & $\begin{array}{c}(3) \\
(63)\end{array}$ & $\begin{array}{c}5 \\
(5)\end{array}$ & $\begin{array}{c}21 \\
(17)\end{array}$ \\
\hline
\end{tabular}

${ }^{*}$ Parenthesis (maximum value attained)

Aph - Aphelenchus spp.; Hel - Helicotylenchus spp.; Hop -Hoplolaimus spp.; Mel - Meloidogyne spp.; Pra -

Pratylenchus spp.; Rot - Rotylenchulus spp.

To know the population abundance of different nematode genera observed in soil samples collected from Attappady hill area they were arranged in the chronological order according to their prominence value. Highest prominence value was achieved by Meloidogyne spp. and was followed by Rotylenchulus spp., Aphelenchus spp., Helicotylenchus spp., Tylenchorynchus spp., Pratylenchus spp., Hoplolaimus spp., Dorylaimoidesspp. and Radopholusspp. While arranging different nematode genera observed in root samples, the chronological order according to their prominence value was Meloidogyne spp., Rotylenchulus spp., Helicotylenchus spp., Aphelenchus spp., Pratylenchus spp. and Hoplolaimus spp. Analysis revealed that the banana fields were severely attacked by plant parasitic nematodes. They are in above ETL (Economic Threshold Level) because the maximum number of nematodes found at Agali panchayath and Sholayur panchayath were 364 per $250 \mathrm{~g}$ and 314 per $250 \mathrm{~g}$ respectively for rhizosphere soil samples. The population density and population abundance of nematodes in each panchayath on cultivar 'Nendran' is given in the Tables $4 \& 5$ for both soil and root samples. 
Table 4. Nematode population densities in rhizosphere soil of banana 'Nendran'(AAB) samples at Attappady hill area

\begin{tabular}{|c|c|c|c|c|}
\hline Nematode genera & $\begin{array}{c}\text { Nematode occurrence } \\
(\%)\end{array}$ & AF distribution & $\begin{array}{c}\text { AD } \\
(\%)\end{array}$ & PV \\
\hline Aphelenchus spp. & 13.61 & 33.33 & 1255.56 & 7248.62 \\
\hline Dorylaimoides spp. & 0.36 & 22.22 & 33.33 & 157.11 \\
\hline Helicotylenchus spp. & 8.42 & 55.56 & 777.78 & 5797.46 \\
\hline Hoplolaimus spp. & 2.78 & 33.33 & 255.56 & 1475.4 \\
\hline Meloidogyne spp. & 48.62 & 100 & 4488.89 & 44888.9 \\
\hline Pratylenchus spp. & 3.37 & 44.44 & 311.11 & 2073.96 \\
\hline Radopholus spp. & 0.24 & 11.11 & 22.22 & 74.06 \\
\hline Rotylenchulus spp. & 18.65 & 100 & 1722.22 & 17222.2 \\
\hline Tylenchorynchus spp. & 3.97 & 33.33 & 366.67 & 2116.86 \\
\hline
\end{tabular}

${ }^{*}$ Note - AF = Absolute frequency; $\mathrm{AD}=$ Absolute density; PV- Prominence value

Table 5. Nematode population densities in root of banana 'Nendran'(AAB) samples at Attappady hill area

\begin{tabular}{|c|c|c|c|c|}
\hline & Nematode occurrence (\%) & AF distribution & $\begin{array}{c}\text { AD } \\
(\%)\end{array}$ & PV \\
\hline Aphelenchus spp. & 4.96 & 33.33 & 388.89 & 2245.15 \\
\hline Helicotylenchus spp. & 8.37 & 55.56 & 655.56 & 4886.45 \\
\hline Hoplolaimus spp. & 0.43 & 11.11 & 33.33 & 111.09 \\
\hline Meloidogyne spp. & 61.28 & 100 & 4800 & 48000 \\
\hline Pratylenchus spp. & 0.71 & 11.11 & 55.56 & 185.19 \\
\hline Rotylenchulus spp. & 24.26 & 88.89 & 1900 & 17913.48 \\
\hline
\end{tabular}

${ }^{*}$ Note $-\mathrm{AF}=$ Absolute frequency; $\mathrm{AD}=$ Absolute density; $\mathrm{PV}=$ Prominence value

\section{Comparison between different banana cultivars for nematode susceptibility}

At the time of comparing different banana cultivars present in Attappady hill area for the presence of nematode population, root analysis was done. From that, the cultivar 'Nendran' was found as most susceptible cultivar found was 'Nendran' and the least susceptible cultivar was 'Poovan (Mysore)'. The root analysis showed that 'Nendran' had a percentage of occurrence of $37.36 \%$ while other cultivars such as 'Robusta' had 22.74\%, 'Kadali' had 22.1\% and 'Poovan' (Mysore) had 17.81\%.

The idea about density of plant parasitic nematodes can be observed by knowing the percentage of occurrence of each observed genera in the rhizosphere soil and root samples. In banana cultivar 'Nendran', percentage of occurrence for the observed genera Meloidogyne spp., Rotylenchulus spp., Aphelenchus spp., Helicotylenchus spp., Tylenchorynchus spp., Pratylenchus spp., Hoplolaimus spp., Dorylaimoides spp. and Radopholus spp. were 48.62\%, 18.65\%, 13.61\%, 8.42\%, 3.97\%, 3.37\%, 2.77\%, 0.36\% and 0.24 respectively. The percentage of occurrence in root samples for the observed genera Meloidogyne spp., Rotylenchulus spp., Helicotylenchus spp., Aphelenchus spp., Pratylenchus spp. and Hoplolaimus spp. were 61.28\%, 24.26\%, $8.37 \%, 4.96 \%, 0.71 \%$ and $0.43 \%$ respectively. In the rhizosphere soil of 'Kadali', order of percentage of occurrence for the genera Rotylenchulus spp., Meloidogyne spp., Dorylaimoides spp. and Hoplolaimus spp. were $46.23 \%, 24.53 \%, 19.81 \%$ and $9.43 \%$ respectively. The chronological order of percentage of occurrence in root samples for the observed genera Meloidogyne spp., Rotylenchulus spp., Dorylaimoides spp. and Hoplolaimus spp. were $38.13 \%, 35.25 \%, 25.18 \%$ and $1.44 \%$ respectively.

The rhizosphere soil of 'Robusta' showed percentage of occurrence for the genera in the order of Dorylaimoides spp., Meloidogyne spp., Radopholus spp., Tylenchus spp. and Rotylenchulus spp. at 30.41\%, 26.32\%, 23.98\%, 10.53\% and 8.77\% respectively. For the root samples the genera Meloidogyne spp., Rotylenchulus spp., Dorylaimoides spp. and Radopholus spp. were occurred at 54.55\%, 25.17\%, 11.19\% and $9.09 \%$ respectively. The order of percentage of occurrence for the observed genera in rhizosphere soil sample of 'Poovan (Mysore)' were Meloidogyne spp. at 67.37\%, Radopholus spp. at 18.95\% and Rotylenchulus spp. at $13.68 \%$ and its order in the root samples were Meloidogyne spp. at 50.89\%, Rotylenchulus spp. at $23.21 \%$, 
Radopholusspp. at $16.07 \%$ and Dorylaimoides spp. at $9.82 \%$. For an easy conveyance, occurrence of nematodes in each cultivar in both rhizosphere soil and root were given in the Tables 6 and 7 and Figures 2 and 3.

Table 6. Nematode population densities in rhizosphere soil of different banana cultivars at Attappady hill area

\begin{tabular}{|c|c|c|c|c|}
\hline Cultivar & Nematode genera observed & $\begin{array}{l}\text { Occurrence of each genera } \\
\text { per cultivar }\end{array}$ & $\begin{array}{l}\text { Mean nematode } \\
\text { count }\end{array}$ & $\begin{array}{c}\text { Nematodes in a } \\
\text { cultivar }(\%)\end{array}$ \\
\hline \multirow{9}{*}{ Nendran } & Aphelenchus spp. & 13.61 & \multirow{9}{*}{$92.33 \pm 11.55$} & \multirow{9}{*}{42.68} \\
\hline & Dorylaimoides spp. & 0.36 & & \\
\hline & Helicotylenchus spp. & 8.42 & & \\
\hline & Hoplolaimus spp. & 2.77 & & \\
\hline & Meloidogyne spp. & 48.62 & & \\
\hline & Pratylenchus spp. & 3.37 & & \\
\hline & Radopholus spp. & 0.24 & & \\
\hline & Rotylenchulus spp. & 18.65 & & \\
\hline & Tylenchorynchus spp. & 3.97 & & \\
\hline \multirow{4}{*}{ Kadali } & Dorylaimoides spp. & 19.81 & \multirow{4}{*}{$35.33 \pm 4.84$} & \multirow{4}{*}{16.33} \\
\hline & Hoplolaimus Spp. & 9.43 & & \\
\hline & Meloidogyne spp. & 24.53 & & \\
\hline & Rotylenchulus spp. & 46.23 & & \\
\hline \multirow{5}{*}{ Robusta } & Dorylaimoides spp. & 30.41 & \multirow{5}{*}{$57 \pm 21.08$} & \multirow{5}{*}{26.35} \\
\hline & Meloidogyne spp. & 26.32 & & \\
\hline & Radopholus spp. & 23.98 & & \\
\hline & Rotylenchulus spp. & 8.77 & & \\
\hline & Tylenchus spp. & 10.53 & & \\
\hline \multirow{3}{*}{$\begin{array}{l}\text { Poovan } \\
\text { (Mysore) }\end{array}$} & Meloidogyne spp. & 67.37 & \multirow{3}{*}{$31.67 \pm 9.06$} & \multirow{3}{*}{14.64} \\
\hline & Radopholus spp. & 18.95 & & \\
\hline & Rotylenchulus spp. & 13.68 & & \\
\hline
\end{tabular}

Table 7. Nematode population densities in root of different banana cultivars at Attappady hill area

\begin{tabular}{|c|c|c|c|c|}
\hline Cultivar & Nematode genera observed & $\begin{array}{l}\text { Occurrence of each } \\
\text { genera per cultivar }\end{array}$ & $\begin{array}{l}\text { Mean nematode } \\
\text { count }\end{array}$ & $\begin{array}{c}\text { Nematodes in a } \\
\text { cultivar (\%) }\end{array}$ \\
\hline \multirow{6}{*}{ Nendran } & Aphelenchus spp. & 4.96 & \multirow{6}{*}{$78.33 \pm 12.70$} & \multirow{6}{*}{37.36} \\
\hline & Helicotylenchus spp. & 8.37 & & \\
\hline & Hoplolaimus spp. & 0.43 & & \\
\hline & Meloidogyne spp. & 61.28 & & \\
\hline & Pratylenchus spp. & 0.71 & & \\
\hline & Rotylenchulus spp. & 24.26 & & \\
\hline \multirow{4}{*}{ Kadali } & Dorylaimoides spp. & 25.18 & \multirow{4}{*}{$46.33 \pm 8.29$} & \multirow{4}{*}{22.1} \\
\hline & Hoplolaimus Spp. & 1.44 & & \\
\hline & Meloidogyne spp. & 38.13 & & \\
\hline & Rotylenchulus spp. & 35.25 & & \\
\hline \multirow{4}{*}{ Robusta } & Dorylaimoides spp. & 11.19 & \multirow{4}{*}{$47.67 \pm 7.31$} & \multirow{4}{*}{22.74} \\
\hline & Meloidogyne spp. & 54.55 & & \\
\hline & Radopholus spp. & 9.09 & & \\
\hline & Rotylenchulus spp. & 25.17 & & \\
\hline \multirow{4}{*}{ Poovan (Mysore) } & Dorylaimoides spp. & 9.82 & \multirow{4}{*}{$37.33 \pm 6.74$} & \multirow{4}{*}{17.81} \\
\hline & Meloidogyne spp. & 50.89 & & \\
\hline & Radopholus spp. & 16.07 & & \\
\hline & Rotylenchulus spp. & 23.21 & & \\
\hline
\end{tabular}




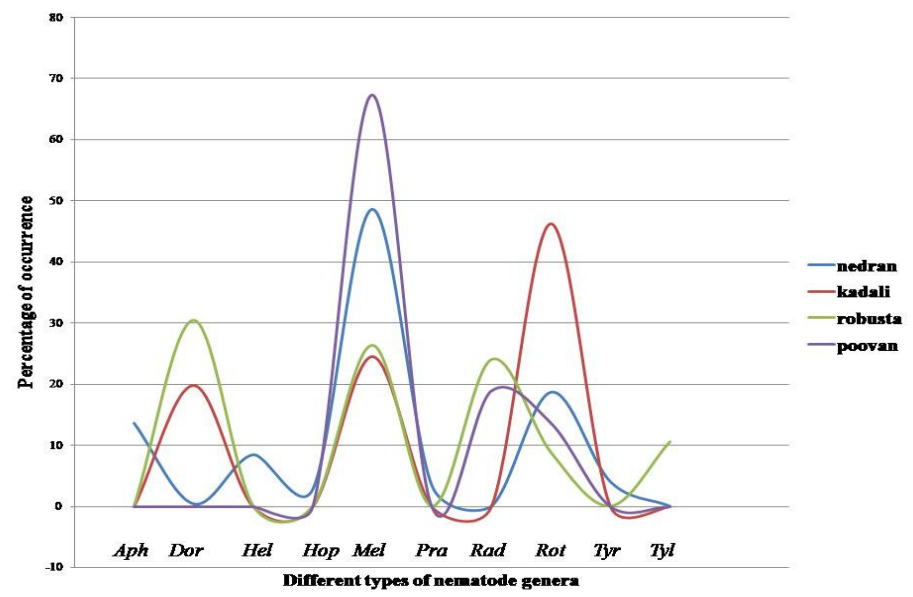

Figure 2. Percentage of occurrence of different plant parasitic nematodes in rhizosphere soil samples from different banana cultivars at Attappady hill area, India

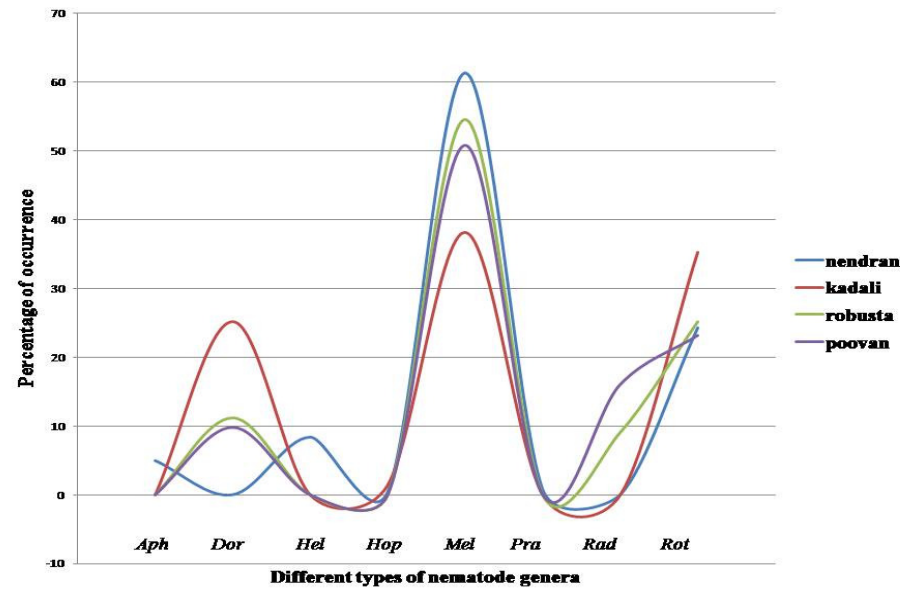

Figure 3. Percentage of occurrence of different plant parasitic nematodes in root samples from different banana cultivars at Attappady hill area, India

The soil analysis of banana cultivars gave the idea that Meloidogyne spp. and Rotylenchulus spp. were the two genera found in all studied cultivars. Among studied cultivars, genera such as Aphelenchus spp., Helicotylenchus spp., Pratylenchus spp. and Tylenchorynchus spp. were found only in 'Nendran'. An interesting result is that the genus Tylenchus spp. was observed only in the rhizosphere soil samples collected from cultivar 'Robusta'. The genera Hoplolaimus spp. was observed in both soil and root samples of the cultivars 'Nendran' and 'Kadali'. Even though Tylenchorynchus spp. and Tylenchus spp. were present in rhizosphere soil samples, they were not found in any of the root samples. While analysing the root samples, Dorylaimoides spp. was observed in all studied cultivars except 'Nendran'. The major banana attacking nematode Radopholusspp. found in all samples except in the cultivar 'Kadali' and in root samples of 'Nendran'. 


\section{Discussion}

'Nendran' is the most prominently cultivating cultivar in this area. So, the agricultural equipments used by farm employers from one field to another may become a media for field to field transfer of nematodes. Present study revealed that Aphelenchus spp., Helicotylenchus spp., Hoplolaimus spp., Meloidogyne spp., Pratylenchus spp., Radopholus spp., Rotylenchulus spp., Tylenchorynchus spp., Tylenchus spp. and Dorylaimoides spp. were the different nematode genera observed in the banana cultivars present in this study area. Ten nematode genera namely Helicotylenchus, Hoplolaimus, Macroposthonia, Meloidogyne, Radopholus, Rotylenchulus, Pratylenchus, Pratylenchus, Tylenchorynchus and Tylenchus were isolated from both soil and roots of banana plants from five sampling areas in Peninsular Malaysia (Rahman et al., 2014). The recovery data for nematodes by Kamira et al. (2013) from roots and soil of banana in eastern and western D.R. Congo also reported almost same genera such as Helicotylenchus dihystera, H. multicinctus, Meloidogyne spp., Pratylenchus goodeyi, Pratylenchus spp., Radopholus similis and Rotylenchulus reniformis. One national range study in India revealed the presence of nematodes associated with banana in Palakkad district were Radopholus similis, Meloidogyne incognita, Helicotylenchus multicinctus, Heterodera oryzicola and Pratylenchus coffeae (Khan et al., 2010). But the present survey conducted at a small area of Palakkad district itself reported the presence of nematode genera such as Hoplolaimus spp., Rotylenchulus spp., Tylenchorynchus spp., Tylenchus spp. and Dorylaimoides spp. which were not reported earlier from samples of both root and rhizosphere soil of banana. Roy et al. (2014) reported the presence of $R$. similis, $H$. multicinctus, and $P$. coffeae as abundant nematode endoparasites of banana from the Indian state Kerala at a low land area. Some earlier reports showed the wide spread occurrence of $M$. incognita, $R$. similis, and P. coffeae in banana plantations (Koshy et al., 1978; Rajendran et al., 1979; Umar and Chubado 2008; Shahzad et al., 2010; Haougui et al., 2011). The study in Nigeria showed that Meloidogyne spp. was the most frequently encountered nematode in that region (Okafor et al., 2015). The most distributed nematode genera of Musa spp. in the present study area also showed the same information. The genera Meloidogyne was the most frequent plant parasitic nematodes in a study conducted at Kenya also (Wachira et al., 2013). Another study on banana nematode population from root samples from all studied eight taluks revealed that Pratylenchus coffeae was the predominant species in Thanjavur district (Srinivasan et al., 2011). Rahman et al. (2014) showed that Rotylenchulus was predominant in the soil samples of banana followed by Meloidogyne incognita. At the same time $M$. incognita was found to occur at the highest frequency in root samples and least frequent one is Tylenchus in the same study by Rahman et al. (2014). But in the present study the situation is reverse. In the present study it was found that Radopholus as the least frequent one. Present study results contradicted the conventional perspective (Sheela et al., 1990; Speijer and De Waele, 1997; Araya et al., 2002; Chávez and Araya, 2010) as we found frequency of occurrence of $R$. similis is rather localized instead of widespread as they were expected to be in banana fields. The occurrence of $R$. similis was found in Pudur Panchayath only. The presence of nematode in root sample gave more valid idea. So, the presence of $R$. similis in root sample of 'Poovan (Mysore)' is a noticing information which is not observed in soil sample of this cultivar.

\section{Conclusions}

From this study, it is clear that the nematode community is a constraint affecting banana production in Attappady hill area, Kerala, India. Based on the numbers on nematodes present in this agriculture area, it can be placed at above Economic Threshold level. All studied cultivars were found affected. The more susceptible banana cultivar observed in this highly important area was 'Nendran'. It is the more prominent and marketable cultivar. So the lost caused by this pathogen should be addressed and care should be taken in an economical and eco-friendly manner. The least susceptible cultivar was found as 'Poovan (Mysore). 


\section{Authors' Contributions}

The research work (Methodology) was jointly conceived and designed by all three authors (ARU). The work carried out and original manuscript draft preparation was done by the first author (A). The data analysis work and review were done by the third author $(\mathrm{U})$ and preliminary and final proof reading (editing) of the manuscript draft was done by the second author $(\mathrm{R})$. In each step of the research, strict supervision was handled by both second and third authors. The authors cooperated in all the experiments, reading and approval of the final manuscript.

\section{Acknowledgements}

This research received no specific grant from any funding agency in the public, commercial, or not-forprofit sectors.

\section{Conflict of Interests}

The authors declare that there are no conflicts of interest related to this article.

\section{References}

Araya M, De Waele D, Vargas R (2002). Occurrence and population densities of nematode parasites of banana (Musa AAA) roots in Costa Rica. Nematropica 32:21-33.

Chávez C, Araya M (2010). Spatial-temporal distribution of plant-parasitic nematodes in banana (Musa AAA) plantations in Ecuador. Journal of Applied Biosciences 33:2057-2069.

Department of Economics and Statistics (2017). Agricultural statistics 2016-2017. Department of Economics and Statistics, Government of Kerala. Retrieved 2018 June 20 from http://www.ecostat.kerala.gov.in/images/pdf/publications/Agriculture/data/2016-17/rep_agristat_1617.pdf

Haougui A, Doumma A, Toufigue BM, Kollo A (2011). Survey of plant parasitic nematodes associated with sweet potato in Niger. Asian Journal of Agricultural Sciences 3(1):32-36.

Jain RK, Mathur KN, Singh RV (2007). Estimation of losses due to plant parasitic nematodes on different crops in India. Indian Journal of Nematology 37:219-221.

Kamira M, Hauser S, van Asten P, Coyne D, Talwana HL (2013). Plant parasitic nematodes of banana and plantain in DR Congo. Nematropica 43:216-225.

Khan MR, Jain RK, Sing RV, Pramanik A (2010). Economically important plant parasitic nematodes distribution atlas. Directorate of Information and Publications of Agriculture, Indian Council of Agricultural Research, New Delhi, India.

Kibria MG, Hoque MA (2005). Musa nematode problems in Bangladesh. In: de la Cruz Jr. FS, Van den Bergh I, De Waele D, Hautea DM, Molina AB (Eds). Towards management of Musa nematodes in Asia and the Pacific. Country reports presented during the training workshop on enhancing capacity for nematode management in small-scale banana cropping systems held at the Institute of Plant Breeding, University of the Philippines pp 3-8.

Koshy PK, Sundararaju P, Sosamma VK (1978). Occurrence and distribution of Radopholus similis (Cobb) thorne in South India. Indian Journal of Nematology 8:49-58.

Norton DC (1978). Ecology of plant parasitic nematodes. John Wiley and Sons. New York, U.S.A pp 268.

Okafor OE, Ugwuoke KI, Mba CL, Okafor FC, Mbadianya JI (2015). The distribution of plant-parasitic nematodes of Musa spp. in Nsukka Agricultural Ecological zone, Enugu State, Nigeria. African Journal of Agricultural Research 4338-4347. https://doi.org/10.5897/AJAR2014.9159

Pinochet J, Stover RH (1980). Fungi associated with nematode lesions on plantains in Honduras. Nematropica 10(2):112-115. 
Quénéhervé P (1989). Integrated management of banana nematodes. In: Ciancio A, Mukerji KG (Eds). Integrated Management of Fruit Crops and Forest Nematodes, Springer, Dordrecht pp 3-61. https://doi.org/10.1007/9781-4020-9858-1_1

Rahman SSA, Zain SM, Mat BM Sidam AK, Othman RY, Mohamed Z (2014). Population distribution of plant-parasitic nematodes of bananas in peninsular Malaysia. Sains Malaysiana 43(2):175-183.

Rajendran G, Naganathan TN, Vadivelu S (1979). Studies on banana nematodes. Indian Journal of Nematology 9:54.

Rajendren G, Bhaktavatsalu CM, Madhava RVN, Abdul KJBM (1980). Banana nematodes. In: Proceedings of the National Seminar on Banana Production Technology. Tamil Nadu Agricultural University, Coimbatore, India, pp 164-167.

Ravichandra NG (2015). Plant nematology. I.K. International Publishing House, Pvt. Ltd., New Delhi.

Rotimi MO (2003). Incidence of plant parasitic nematodes on plantain (Musa spp., AAB) in Nigeria and their effect on root health, plant growth and yield. InfoMusa 12(2):41.

Roy K, Roy S, Sarkar S, Rathod A, Pramanik A (2014). Diversity of migratory nematode endoparasites of banana. Journal of Crop and Weed 10(2):375-391.

Shahzad A, Atfghan S, Javed N, Hussain K, Hussnain ZU, Ali K, ... Niaz M (2010). Population dynamics of plant parasitic nematodes of central Punjab, Pakistan. Pakistan Journal of Nematology 28(2):341-351.

Sheela MS, Jacob AJ, Kuriyan JK (1990). Surveillance of plant parasitic nematodes of different crops in homesteads of Kerala. Indian Journal of Nematology 20(2):172-176.

Sheth K (2017). Top banana producing countries in the world. Retrieved 2017 April 25 from https://www.worldatlas.com/articles/top-banana-producing-countries-in-the-world.html

Southey JF (1986). Laboratory methods for work with plant and soil nematodes. Ministry of agriculture, Fisheries and Food, HMSO, London pp 202.

Speijer PR, De Waele D (1997). Screening of Musa germplasm for resistance and tolerance to nematodes. Montpellier: International Network for the Improvement of Banana and Plantain (INIBAP) Technical Guidelines pp 1-47.

Srinivasan R, Kulothungan S, Sundararaju P, Govindasamy C (2011). Biodiversity of plant parasitic nematodes associated with banana in Thanjavur district of Tamilnadu. International Journal of Plant, Animal and Environmental Sciences 1(2):63-69.

Umar I, Chubado D (2008). Survey of plant parasitic nematodes in the Beny valley of Andamawa State Nigeria. Agricultural Journal 3(5):353-356.

Wachira PM, Kimenju JW, Kiarie JW, Kihurani AW, Mwaniki SW, Gathaara VN (2013). Incidence of pests and diseases affecting banana in a commercial banana production setting in Kenya. International Journal of Research in Agriculture and Food Sciences 1(1):23-29.
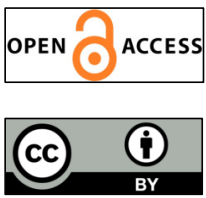

The journal offers free, immediate, and unrestricted access to peer-reviewed research and scholarly work. Users are allowed to read, download, copy, distribute, print, search, or link to the full texts of the articles, or use them for any other lawful purpose, without asking prior permission from the publisher or the author.

License - Articles published in Notulae Scientia Biologicae are Open-Access, distributed under the terms and conditions of the Creative Commons Attribution (CC BY 4.0) License.

(c) Articles by the authors; SHST, Cluj-Napoca, Romania. The journal allows the author(s) to hold the copyright/to retain publishing rights without restriction. 